\title{
ASSESSMENT OF SEED-BORNE PLANT PATHOGENIC FUNGI, INSECT EMERGENCE AND PERCENTAGE GERMINABILITY ASSOCIATED WITH HARVESTED AND STORED RICE IN KWARA STATE, NIGERIA
}

\author{
Aremu M. B. ${ }^{1 *}$, Kurah I. A. ${ }^{1}$, Okparavero N. F. ${ }^{1}$, Okunade S. O. ${ }^{1}$, Adebola M. O. ${ }^{2}$, \\ Rahman M. O. ${ }^{1}$ and Aina O. B. ${ }^{1}$ \\ ${ }^{1}$ Nigerian Stored Products Research Institute, KM 3, Asa Dam Road, Ilorin, Kwara State \\ ${ }^{2}$ Federal University of Technology Minna, Niger State, Nigeria \\ *Corresponding Email: mariambukola036@yahoo.com
}

\section{Cite this article:}

Aremu M.B., Kurah I.A., Okparavero N.F., Okunade S.O., Adebola M.O., Rahman M.O., Aina O.B. (2021), Assessment of Seed-Borne Plant Pathogenic Fungi, Insect Emergence and Percentage Germinability Associated with Harvested and Stored Rice in Kwara State, Nigeria. African Journal of Agriculture and Food Science 4(2), 44-54. DOI: $10.52589 / A J A F S-$ OY9AE3MW.

\section{Manuscript History \\ Received: 5 May 2021 \\ Accepted: 27 May 2021 \\ Published: 12 June 2021}

Copyright $\odot 2020$ The Author(s). This is an Open Access article distributed under the terms of Creative Commons Attribution-NonCommercialNoDerivatives 4.0 International (CC BY-NC-ND 4.0), which permits anyone to share, use, reproduce and redistribute in any medium, provided the original author and source are credited.
ABSTRACT: This study was conducted to assess the incidence of seed-borne fungi, insect emergence as it affect the germinability rate of rice seed collected from the major rice growing areas of Kwara State, Nigeria, The rice seeds were collected during the dry season of 2019. Five (5) fungi species were isolated from all the rice samples. The incidence of fungi pathogens vary from one locality to another, as well as the frequency of occurrence. The pathogens isolated include Fusarium. oxysporium, Aspergillus spp., Aspergillus flavus, Aspergillus fumigatus., Cladosporium sp., Mucor sp. FARO 44 rice variety has the highest incidence of fungal pathogen(12.5× $10^{4}$ ) while local varieties Alhaji Sule and Kuddo has the lowest incidence of $\left(0.5 \times 10^{4}\right)$ respectively. Penicillium sp. has the highest percentage frequency of occurrence (49.3\%) while cladosporium sp has lowest (1.33\%) across all samples. Sample 9(F-52), 15(E) and 17(K) has the lowest percentage germinability of 41,40 and $45 \%$ while sample $11(A B)$ and $8(K)$ has the highest percentage germinability of $84 \%$ and $77 \%$ respectively. All the samples do not have the most serious damaging insect infestation of Sitophilus oryzae but some of the sample has infestation of some other insects such as Rhyzopertha dominca, a lesser grain borer and a primary stored pest of cereals, Tribolium. castaneum a secondary pest and some other unidentified insects in varying percentage. Measures such as lowest moisture content of seed meant for storage and proper cleaning of the store must be put in place to avoid seed deterioration as a result of seed borne fungal pathogen and insect infestation.

KEYWORDS: Rice, Seed, Fungal, Incidence, Insect, Emergence, Germinability. 


\section{INTRODUCTION}

Rice, Oryzae sativa (L.) is an important staple food crop that is consumed in every household in Nigeria (Udemezue 2014). According to Udemezue (2018), rice is the world's second most important cereal crop following only corn; it is one of the food crops mostly grown in tropical and sub-tropical regions of the world. It is relatively easy to produce and is grown for sale as well as for home consumption Iwuagwu et al, (2018). Local dishes prepared with rice in Nigeria most especially the northern part include "Masa", or "Waina", "Tuwo", and "Alkakki", while the most common form of food prepared with rice all over the country include pudding and boiled form; eaten with stew or combined with potatoes, yam, beans and pears (Oludare, 2014). Nigeria is currently the largest rice producing country in Africa (Akaeze, 2010). This is as a result of conscientious efforts by the current administration to place more emphasis on agrarian production (Udemezue, 2018).

Though Nigeria is the highest producer of rice in Africa, however the percentage population growth rate annually is incommensurate with the total amount of rice produced annually (USDA /Grain report 2019). The population, projected to grow to 392 million by 2050 which apparently will make Nigeria the world's fourth most populous country. This population is increasingly reliant on domestic and imported processed food products (USDA/Grain report 2019). Hence the need to prevent losses/ reduction in quality and quantity of this produce has become a paramount concern. The primary problems of rice causing devastation to farmers are pests and diseases causing deterioration of the seeds by damaging the plumule and radicle that makes up the embryo in the endosperm of the seed thereby rendering the seed not viable for replanting (Ezeji, 2009; Omofonmwan and Kadiri 2007). The North central agroecological zone has the potential for achieving national self sufficiency in rice production. However, the yield of this crop has never been able to meet the growing demand as a result of disease infestation.

Seed health testing to detect seed-borne pathogens is an important step in the management of crop diseases (Ora et al., 2011). It identifies the cause of seed infection that affects the planting value of seed lots. Farmers' awareness about the effect of diseased seeds on their production is important and that several routine activities needs to be undertaken during storage in other to reduce lost. These include dry seed inspection, the standard blotter test for seed infection and contamination, post entry planting for field inspection of undetected plant diseases of seed-borne and seed-contaminated pathogens (Mew and Gonzales, 2002). Seed health testing procedure involves techniques, such as direct examination of dry seeds, examination of germinated seeds, as well as examination of organism (insects and fungal). This study was carried out to assess seed borne plant pathogenic fungal, emergence of insect and its effect on the viability of the seeds in the different rice samples. 


\section{MATERIALS AND METHODS}

\section{Collection of seed samples}

Rice seeds were collected from local rice farmers from the major rice producing localities of Edu Local Government Area (LGA) of Kwara state, Nigeria. The number of varieties collected depended on the available ones planted in each area. The villages visited included Kpotunko, Ekko, Lafiagi, Elumaba, Funti, Gbatigi, Puta, Ganagagi, Esun, Putata, Edogi dukun, Emigi ladan and Dzangy . The rice varieties/ lines collected include FARO 52, FARO 44, kuddo, Alhaji Baba, Rabach, Dgwagwa, Ekangi, Sakpefu and Alhaji Sule

Twenty-one (21) Rice samples were collected from farmers in 13 rice growing villages, across Edu local government area of Kwara State. Collected rice samples of identified local cultivars/varieties were packed in brown envelope, sealed and stored at $4^{0} \mathrm{C}$ until further use. The analysis was carried out at the Microbiology and Entomology laboratory of Nigerian Stored Products Research Institute, Ilorin

\section{Screening for seed-fungi from samples collected using Agar plate method}

\section{Preparation of Potato Dextrose Agar Media}

Thirty nine (39) gram of PDA (Hi-media) was suspended in $1000 \mathrm{ml}$ distilled water and heated to dissolve the powder completely, the medium was sterilized by autoclaving at $121^{\mathrm{O}} \mathrm{C}$ for 15 minutes (Aremu et al., 2013).

\section{Enumeration and Isolation of Fungi}

A serial dilution technique was used where $10 \mathrm{~g}$ of each paddy rice sample was aseptically transferred into $90 \mathrm{ml}$ sterile distilled water in $250 \mathrm{ml}$ conical flask. This was shaken properly to allow even distribution of microorganisms present in the sample. A dilution factor $10^{-4}$ was used as stock solution. Thereafter $1 \mathrm{ml}$ of the dilution was aseptically taken from the suspension and transferred into sterile Petri dishes and $10 \mathrm{ml}$ of PDA was pour into the petri dish with $1 \mathrm{ml}$ chlorophenicol. The plates were swirled gently to allow even distribution of the sample. Incubation was done at temperature of $28^{0} \mathrm{c} \pm 2^{0} \mathrm{c}$ for $72 \mathrm{hrs}$. Enumeration was carried out and subculture was made from mix mycological monograghs (Cannon and Kirk, 2007; Adebola and Amadi, 2012).

\section{Germinability Test.}

Twenty five (25) seeds from each samples were randomly picked respectively from each samples and placed inside a triplicate set of Petri dish containing moisten cotton wool. The seeds were observed for germination for 2 weeks (Vidotto and Ferrero 2000). The numbers that germinated were counted and recorded and percentage germinated determined using this formular:

\%germination $=\underline{\text { number of seed germinated }} \quad \mathrm{x} \quad \underline{100}$




\section{Insect Emergence}

One hundred (100) gram of the paddy rice samples were weighed in a 1-litre Kilner jar in triplicate covered with muslin cloth and secured with a rubber band to serve as a source of aeration and prevent the escape of insect. Each of the weighted rice samples will be placed in an incubator respectively for 21 days to observe for insect emergence (Perez-Mendoza et al., 2004).

\section{RESULTS AND DISCUSSION}

The result of assessment of seed-borne fungi associated with rice seeds across the rice growing area of kwara State showed that the fungal incidence is as high as $12.5 \times 10^{4}$ in FARO 44 and as low as $0.5 \times 10^{4}$ in Local variety Kuddo (Table 1).

\section{Table 1: Fungal Enumeration}

\begin{tabular}{lll}
\hline Samples no & Rice Cultivars/Varieties & Fungal Incidence \\
\hline 1 & DG & $5 \times 10^{4}$ \\
2 & K & $4.5 \times 10^{4}$ \\
3 & F-44 & $12.5 \times 10^{4}$ \\
4 & AB & $4 \times 10^{4}$ \\
5 & R & $1 \times 10^{4}$ \\
6 & AB & $6.5 \times 10^{4}$ \\
7 & F-52 & $1 \times 10^{4}$ \\
8 & K & $1 \times 10^{4}$ \\
9 & F-52 & $1 \times 10^{4}$ \\
10 & K & $11.5 \times 10^{4}$ \\
11 & AB & $1 \times 10^{4}$ \\
12 & K & $4 \times 10^{4}$ \\
13 & S & $2.5 \times 10^{4}$ \\
14 & K & $2.5 \times 10^{4}$ \\
15 & E & $2 \times 10^{4}$ \\
16 & K & $4 \times 10^{4}$ \\
17 & K & $1.5 \times 10^{4}$ \\
18 & F-52 & $3.5 \times 10^{4}$ \\
19 & AS & $0.5 \times 10^{4}$ \\
20 & K & $0.5 \times 10^{4}$ \\
21 & F-54 & $7.5 \times 10^{4}$ \\
\hline & & \\
\hline
\end{tabular}

The associated fungi isolated and identified were group into four genera and six species. These include Fusarium oxysporium, Aspergillus niger, Aspergillus flavus, Aspergillus fumigatus., Collectotrichum sp., and Mucor (Table 2) 
Table 2. Morphological Properties and Microscopic Identification of Fungal Isolates

\begin{tabular}{|c|c|c|c|}
\hline Texture & Macroscopic view & Microscopic identification & Organisms \\
\hline Velvety & $\begin{array}{l}\text { Light green/yellowish } \\
\text { colony with white to cream }\end{array}$ & $\begin{array}{l}\text { Sepate hyphae, unbranched } \\
\text { conidiophores scanty sterigmata }\end{array}$ & $\begin{array}{l}\text { Aspergillus } \\
\text { flavus }\end{array}$ \\
\hline Powdery & $\begin{array}{l}\text { Dark green colony with } \\
\text { whitening powdery that } \\
\text { grows moderately. The } \\
\text { reverse side is cream }\end{array}$ & $\begin{array}{l}\text { Septate hyphae, unbranched } \\
\text { conidiophores with secondary } \\
\text { branches metulas. Sterigmata } \\
\text { bears round conidia in chain }\end{array}$ & $\begin{array}{l}\text { Aspergillus } \\
\text { fumigatus }\end{array}$ \\
\hline Floppy & $\begin{array}{l}\text { Orange colony with white } \\
\text { ring at the edge that is } \\
\text { orange in the reversed }\end{array}$ & $\begin{array}{l}\text { Sepate hyphae, side shaped } \\
\text { macroconidia, conidiophores } \\
\text { bears conidia containing } \\
\text { conidiospores }\end{array}$ & $\begin{array}{l}\text { Fusarium } \\
\text { sp. }\end{array}$ \\
\hline Velvety & $\begin{array}{l}\text { Whitish to black pigment } \\
\text { that latertum, with conidial } \\
\text { production, brownish red } \\
\text { on the reversed side }\end{array}$ & $\begin{array}{l}\text { Septate hyphae, unbranched } \\
\text { conidiophores from the foot of } \\
\text { species }\end{array}$ & $\begin{array}{l}\text { Aspergillus } \\
\text { niger }\end{array}$ \\
\hline Fluffy & $\begin{array}{l}\text { White at early growth } \\
\text { which later became grayish } \\
\text { brown. White at the } \\
\text { reversed side. }\end{array}$ & $\begin{array}{l}\text { Nonseptate or sparsely septate, } \\
\text { broad hyphae, short, erect } \\
\text { sporangiophores taper towards } \\
\text { apices. Sporangium is round. }\end{array}$ & Mucor sp \\
\hline $\begin{array}{l}\text { Cottony/ } \\
\text { velvety }\end{array}$ & $\begin{array}{l}\text { Salmon to red colony on } \\
\text { both front and reserve sides } \\
\text { with white edge }\end{array}$ & $\begin{array}{l}\text { Cylindrical aseptate conidia } \\
\text { hyaline with rounded ends } \\
\text { coalesced together }\end{array}$ & $\begin{array}{l}\text { Collectotric } \\
\text { hum sp }\end{array}$ \\
\hline
\end{tabular}

The result (Table 3) also showed that Aspergillus fumigatus has the highest percentage frequency of occurrence $(49 \pm 33 \mathrm{a})$ which was isolated from seventeen rice samples. This fungus was followed by Aspergillus flavus $(22 \pm 00 \mathrm{~b})$ and Fusarium $s p(14 \pm 00 \mathrm{c})$ which was isolated from nine rice samples, however both A. flavus and A.fumigatus have been reported to be aflatoxin strains while Collectotrichum $s p$ has the least percentage frequency of occurrence $(1 \pm 33 \mathrm{e})$..

Table 3: Frequency of Fungi Isolates from all the paddy Rice samples

\begin{tabular}{lc}
\hline Isolated fungi & Percentage frequency of occurrence across all the samples \\
\hline Aspergillus flavus & $22 \pm 00 \mathrm{~b}$ \\
Aspergillus fumigates & $49 \pm 33 \mathrm{a}$ \\
Fusarium $s p$ & $14 \pm 00 \mathrm{c}$ \\
Aspergillus niger & $5 \pm 33 \mathrm{~d}$ \\
Collectotrichum sp & $1 \pm 33 \mathrm{e}$ \\
Mucor sp & $8 \pm 01 \mathrm{~d}$ \\
\hline
\end{tabular}


African Journal of Agriculture and Food Science

ISSN: 2689-5331

Volume 4, Issue 2, 2021 (pp. 44-54)

www.abjournals.org

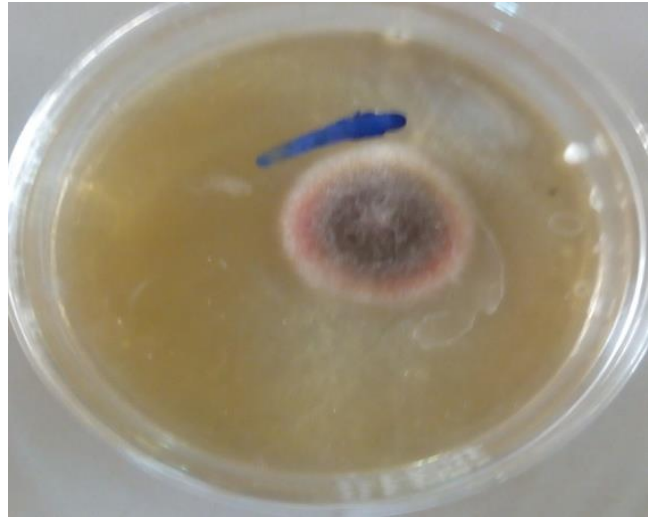

Pure culture of Collectotrichum sp

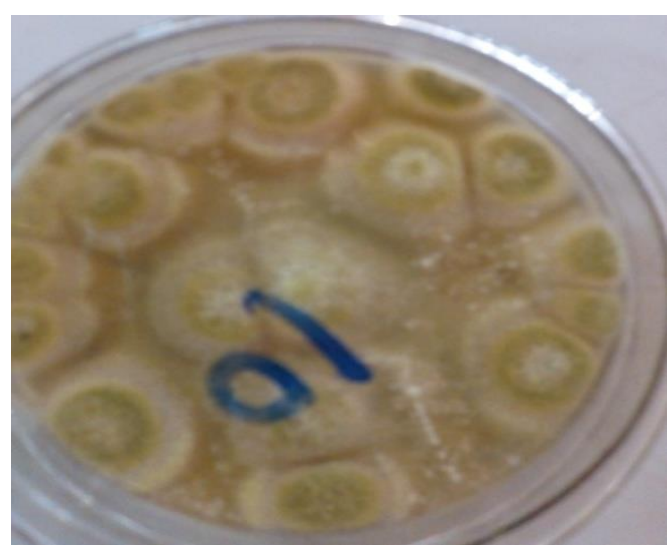

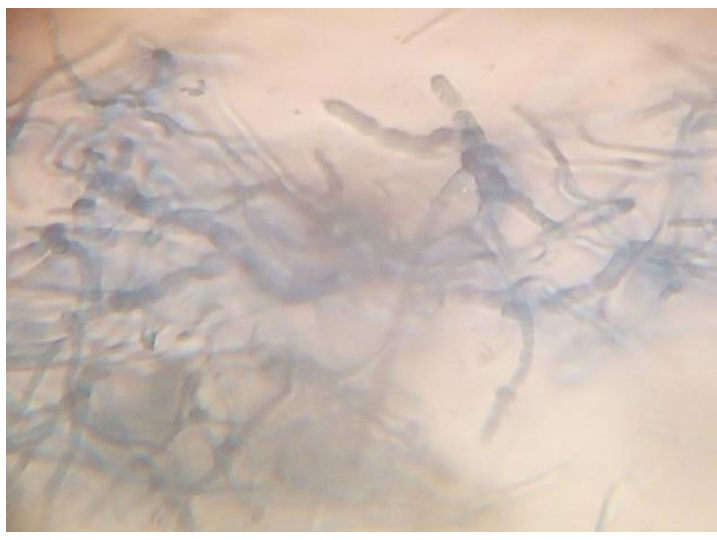

Micrograph of Collectotrichum sp

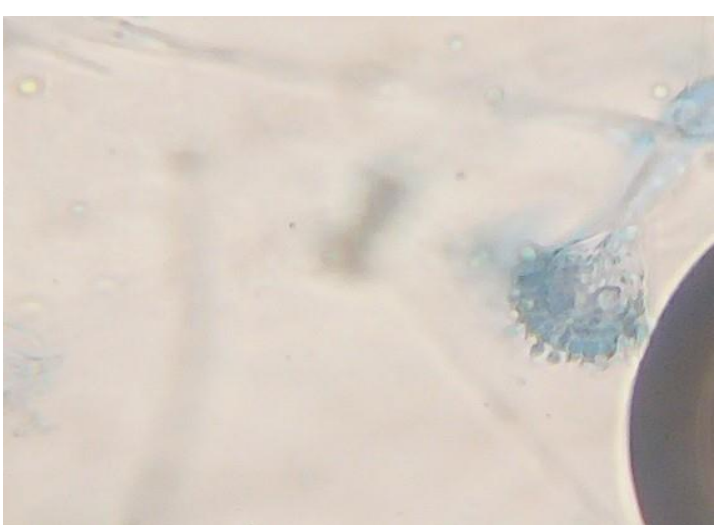

Pure culture of Aspergillus flavus Micrograph of Aspergillus flavus

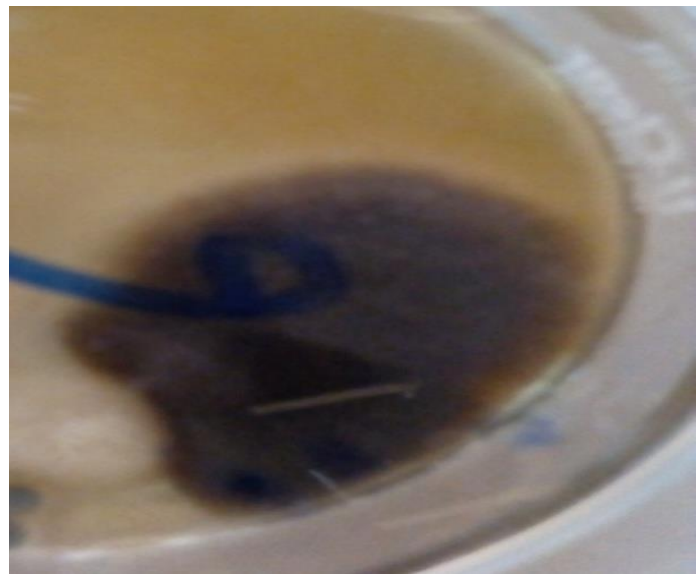

Pure culture of Aspergillus niger

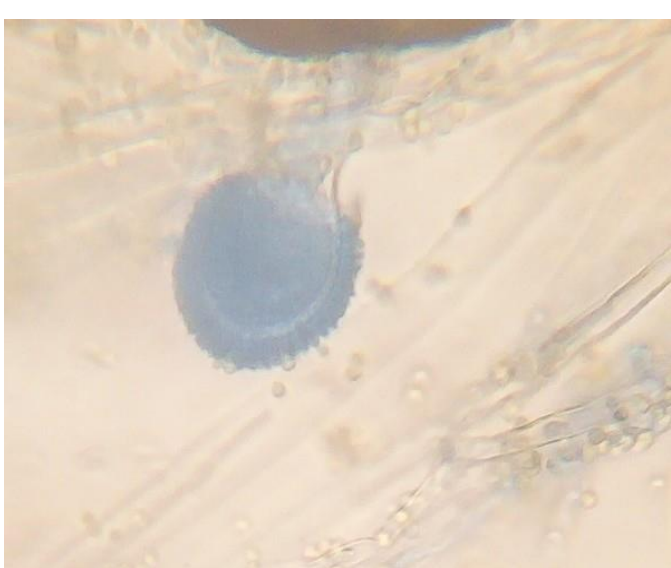

Micrograph of Aspergillus niger 
African Journal of Agriculture and Food Science

ISSN: 2689-5331

Volume 4, Issue 2, 2021 (pp. 44-54)

www.abjournals.org
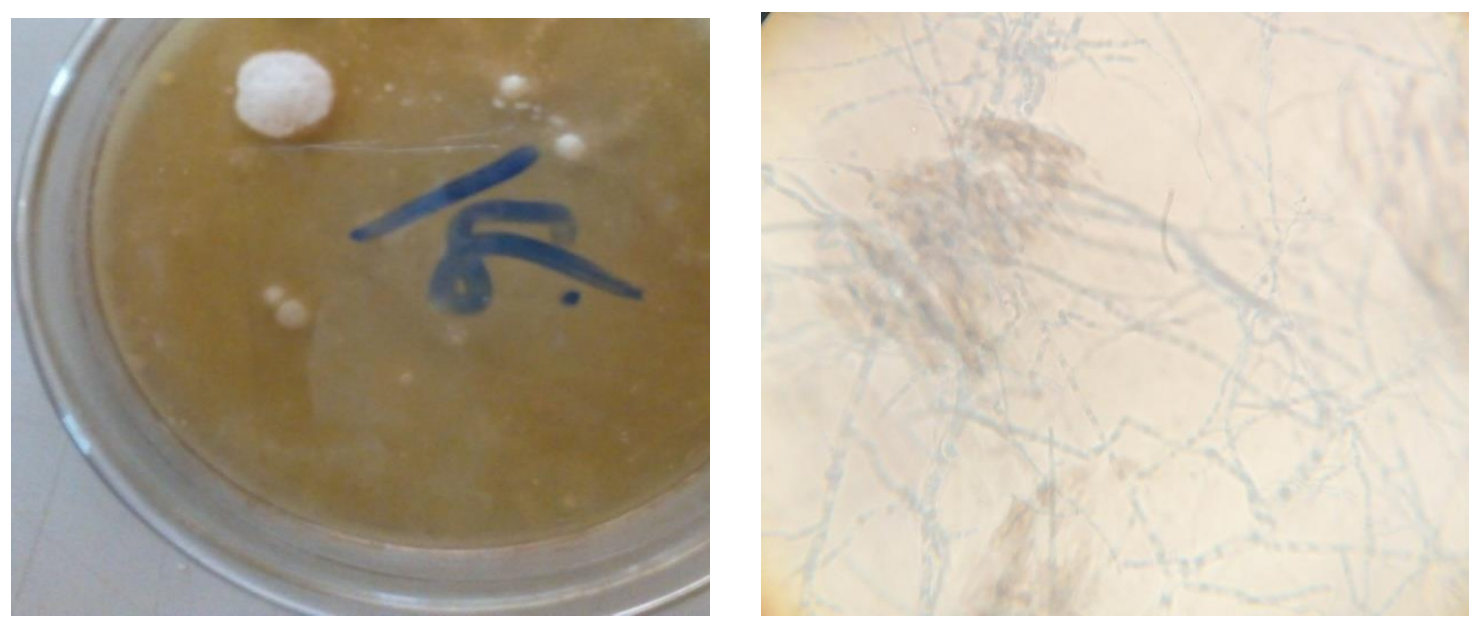

Pure culture of Fusarium sp

Micrograph of Fusarium sp
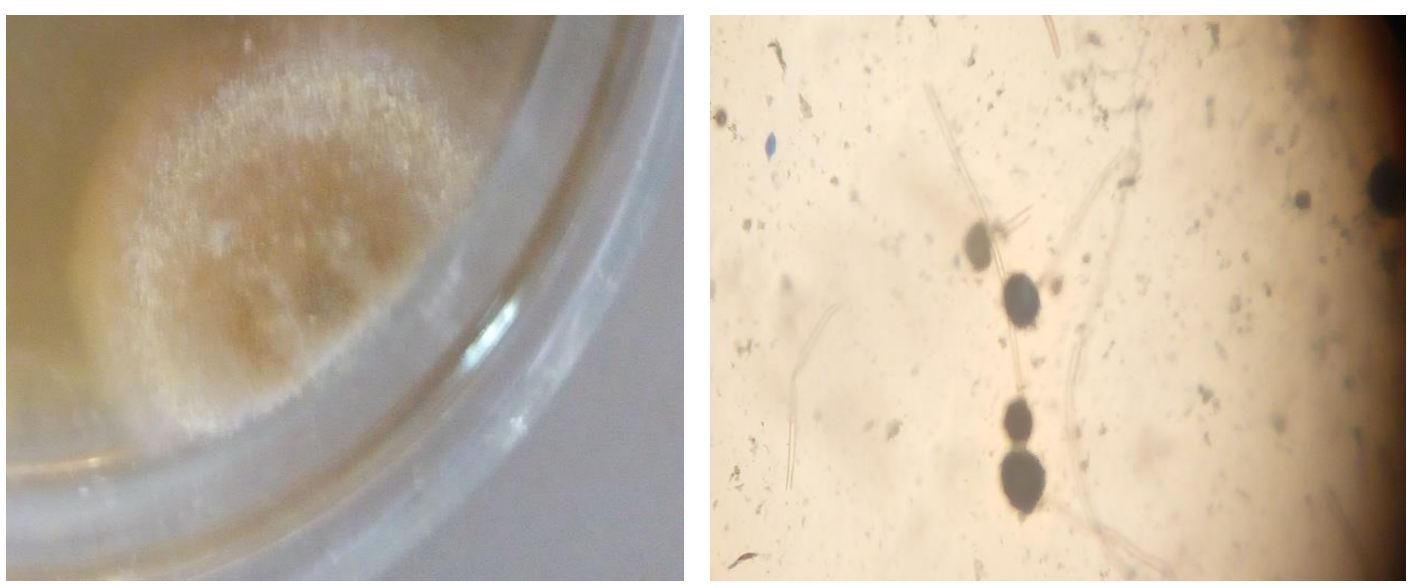

Pure culture of Mucor sp

Micrograph of Mucor sp

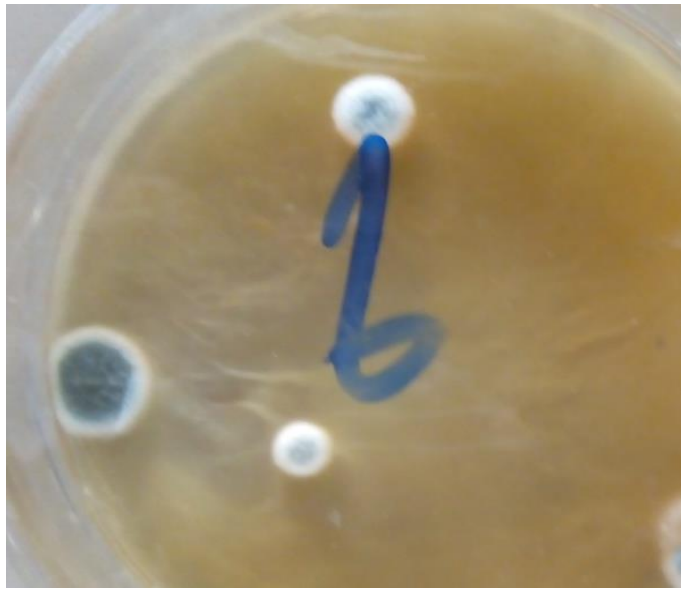

Pure culture of Aspergillus fumigatus

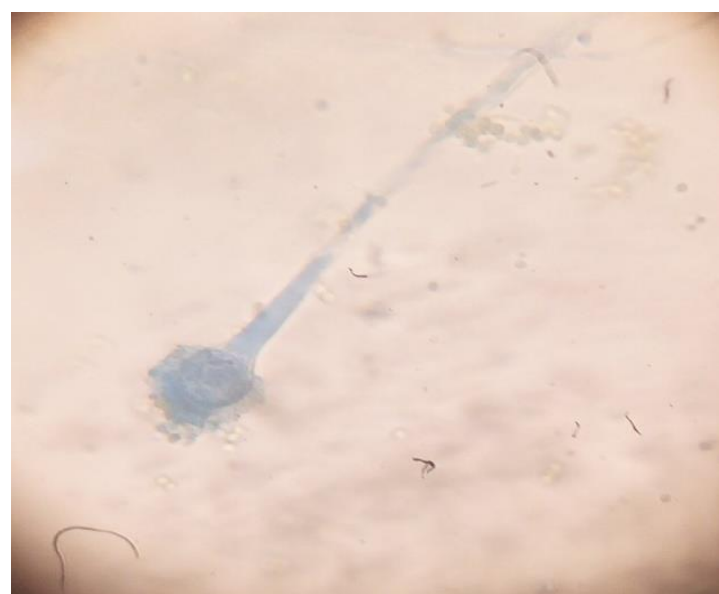

Micrograph of Aspergillus fumigatus 
The result of the disease survey in rice producing areas of Kwara State revealed that rice seeds collected from the various rice producing communities were infected with fungi organisms and infested with insects which affect the germinability percentage in varying degree. Most of these fungi organisms have been found to be pathogenic to rice seeds, causing various damages, such as loss of viability, poor seedling growth, poor rice stand, poor yield and generally economic loss to rice farmers in the area.

This result agrees with the earlier work of Imohelin (1983) which isolated fungi organisms, such as H. oryzae, C.orzzae, Aspergillus spp. etc. from rice seeds in Edo State of Nigeria. He reported that $F$. moniliforme being the third highest frequently occurring organisms in that zone has been known to cause poor seed germination discoloration of rice seeds. Also, its frequent isolation from rice seeds indicates that it may contribute to poor seed quality of Nigerian processed rice

This result is in agreement with the work of Suleiman and Akaajime (2010) who isolated A.niger and R. oryzae from rice seeds in the area of study. According to them, although these organisms are regarded as surface contaminants, they were also frequently observed on infected rice grains. Also besides the fact that some Aspergillus sp. Produces aflatoxins, they have also been shown to deteriorate stored grains. T. padwickii was isolated from rice seeds from Abakaliki area and from the plant materials in the nursery and field. This result is in agreement with that of Utobo et al. (2011) who reported that T. padwickii was the most frequently isolated seedborne fungi irrespective of the source of the rice variety tested in their study.

Table 4: Results of the percentage germinability and the Mean/Standard Error

\begin{tabular}{rcll}
\hline Locations & Rice type & \%GERMINABILITY & MEAN AND STANDARD ERROR \\
\hline 1 & DG & 63.33 & $61.33 \pm 2.67^{\text {bcdef }}$ \\
2 & K & 54.68 & $54.67 \pm 7.06^{\text {abcd }}$ \\
3 & F-44 & 74.67 & $74.67 \pm 3.13^{\text {efg }}$ \\
4 & AB & 66.67 & $66.67 \pm 1.33^{\text {cdefg }}$ \\
5 & R & 74.68 & $74.67 \pm 2.67^{\text {efg }}$ \\
6 & AB & 50.68 & $50.67 \pm 6.67^{\text {abc }}$ \\
7 & F-52 & 57.32 & $57.33 \pm 9.33^{\text {abcde }}$ \\
8 & $\mathrm{~K}$ & 77.33 & $77.33 \pm 3.53^{\text {fg }}$ \\
9 & F-52 & 41.32 & $41.33 \pm 2.67^{\mathrm{a}}$ \\
10 & $\mathrm{~K}$ & 61.32 & $61.33 \pm 7.06^{\text {bcdef }}$ \\
11 & AB & 84.00 & $84.00 \pm 4.61^{\mathrm{g}}$ \\
12 & $\mathrm{~K}$ & 64.00 & $64.00 \pm 4.00^{\text {cdef }}$ \\
13 & $\mathrm{~S}$ & 69.32 & $69.33 \pm 1.33^{\text {defg }}$ \\
14 & $\mathrm{~K}$ & 66.68 & $66.67 \pm 3.52^{\text {cdefg }}$ \\
15 & $\mathrm{E}$ & 40.00 & $40.00 \pm 0.00^{\mathrm{a}}$ \\
16 & $\mathrm{~K}$ & 57.32 & $57.33 \pm 4.80^{\text {abcde }}$ \\
17 & $\mathrm{~K}$ & 45.32 & $45.33 \pm 4.81^{\mathrm{ab}}$ \\
18 & $\mathrm{~F}-52$ & 69.69 & $61.33 \pm 10.41^{\text {bcdef }}$ \\
19 & $\mathrm{AS}$ & 68.00 & $68.67 \pm 6.11^{\text {cdefg }}$ \\
20 & $\mathrm{~K}$ & 65.32 & $65.33 \pm 9.33^{\text {cdef }}$ \\
21 & F-54 & 60.00 & $60.00 \pm 0.00^{\text {bcdef }}$ \\
\hline
\end{tabular}


Based on the samples collected from the different Farmers stores, percentage germinability test was calculated and the viability of seed was analysed using the software program SPSS 17.0 (SPSS Inc., Chicago, Illinois, USA, 2008).

The result (Table 4) shows that there is no significant difference in the percentage germinability in most of the samples across all locations, except sample $9\left(41.33 \pm 2.67^{\mathrm{a}}\right), 15$ $\left(40.00 \pm 0.00^{\mathrm{a}}\right)$ and $17\left(45.33 \pm 4.81^{\mathrm{ab}}\right)$ which are significantly low compared to sample 11 $\left(84.00 \pm 4.61^{\mathrm{g}}\right)$ and $8\left(77.33 \pm 3.53^{\mathrm{fg}}\right)$ where the percentage germinability was significantly high and are different from samples collected. This implies that, despite the significant differences in the percentage germinability, most of the seeds samples collected had above 50 percent germination. The result is in line with the report of Pritchard and Dickie (2004) who reported different crops been able to maintain 50 per cent germination.

Table 5: Result of the percentage Insect Emergence from the samples

\begin{tabular}{cccccc}
\hline Sample & S. oryzae & $R$. dominica & $T$. castaneum & Others & Total No. of insect \\
\hline 1 & $(0 \%)$ & $(32 \%)$ & $(36 \%)$ & $(32 \%)$ & 25 \\
2 & $(0 \%)$ & $(22 \%)$ & $(28 \%)$ & $(50 \%)$ & 18 \\
3 & $(0 \%)$ & $(0 \%)$ & $(50 \%)$ & $(50 \%)$ & 10 \\
4 & $(0 \%)$ & $(33.3 \%)$ & $(33 \%)$ & $(33.3 \%)$ & 15 \\
5 & $(0 \%)$ & $(0 \%)$ & $(0 \%)$ & $(100 \%)$ & 5 \\
6 & $(0 \%)$ & $(0 \%)$ & $(0 \%)$ & $(0 \%)$ & 0 \\
7 & $(0 \%)$ & $(33 \%)$ & $(25 \%)$ & $(42 \%)$ & 12 \\
8 & $(0 \%)$ & $(28 \%)$ & $(28.55)$ & $(43 \%)$ & 28 \\
9 & $(0 \%)$ & $(0 \%)$ & $(5 \%)$ & $(0 \%)$ & 0 \\
10 & $(0 \%)$ & $(0 \%)$ & $(0 \%)$ & $(0 \%)$ & 0 \\
11 & $(0 \%)$ & $(0 \%)$ & $(0 \%)$ & $(100 \%)$ & 3 \\
12 & $(0 \%)$ & $(13 \%)$ & $42 \%)$ & $(45 \%)$ & 24 \\
13 & $(0 \%)$ & $(39 \%)$ & $(43 \%)$ & $(18 \%)$ & 23 \\
14 & $(0 \%)$ & $(45 \%)$ & $(36 \%)$ & $(19 \%)$ & 22 \\
15 & $(0 \%)$ & $(5 \%)$ & $(0 \%)$ & $(0 \%)$ & 0 \\
16 & $(0 \%)$ & $(40 \%)$ & $(30 \%)$ & $(30 \%)$ & 10 \\
17 & $(0 \%)$ & $(0 \%)$ & $(44 \%)$ & $(56 \%)$ & 18 \\
18 & $(0 \%)$ & $(0 \%)$ & $(0 \%)$ & $(100 \%)$ & 3 \\
19 & $(0 \%)$ & $(0 \%)$ & $(0 \%)$ & $(100 \%)$ & 6 \\
20 & $(0 \%)$ & $(26 \%)$ & $(50 \%)$ & $(20 \%)$ & 38 \\
21 & $(0 \%)$ & $(41.2 \%)$ & $(29.4 \%)$ & $(29.4 \%)$ & 17 \\
\hline Sample total 0 & & 72 & & 98 & 107 \\
277 & & & & & \\
\hline
\end{tabular}

\begin{tabular}{llllll} 
Total $(\%)$ & $\mathbf{0 \%}$ & $\mathbf{2 6 \%}$ & $\mathbf{3 5 \%}$ & $\mathbf{3 9 \%}$ & $100 \%$ \\
\hline
\end{tabular} 
The results of the percentage insect emergence (table 5) shows that all the samples collected do not have $S$. oryzae infestation while some of the samples have $R$. dominica and $T$. castaneum in different percentages, Some other un- identified insects that may have one effects or the other on rice seeds were also recorded which might probably find their way into the seeds during bagging or transportation or as a results of storing different types of grains in the same storage facility The total insect emergence from the 21 paddy rice samples was 227, Sitophilus oryzea, Ryzopertha dominica, T. castaneum, and other species of insects represented 0, 72, 98 and 107 respectively. Sitophilus oryzea accounts for 0\%, Ryzopertha dominica accounts for $26 \%, T$. castaneum accounts for $35 \%$, and other insect species found in the samples accounts for $39 \%$ of the insect emergence. However, high total insect emergence was observed in most of the samples i.e. 1, 2, 3, 4, 7, 8, 12, 13, 14, 16, 17. 20 and 21 where Ryzopertha dominica a lesser grain borer and a primary stored pest of cereals and Tribolium castaneum a secondary pest were found to be predominant in these samples. According to Emery and Nayak (2007) who reported that R.dominica is a major pest of wheat and rice around the world, both the larva and the adult produce frass and cause weight losses by feeding on the grains thereby reducing the grains to dust. This insect, eventually creates an avenue for opportunistic insect (secondary insects) which do not have the ability of making their way into the grain thereby feeding on the frass from the primary insect, hence reducing the quality and quantity of the grain. The result is in line with the findings of Togola et al. (2013) who reported $S$. oryzae and $R$. dominca as the most damaging insect of stored paddy rice. However most of the samples that has high incidence of fungal infection as well as insect emergence also have above 50 percent seed germination

\section{REFERENCE}

Adebola, M. O. \& Amadi, J. E. (2012). The Efficacy of paecilomyces specie and Penicillium digitatum on Black pod Disease pathogen on the field. European Journal of Applied Science, 4(3), 101-104

Adedire, C. O,, \& Ladeji, L.(2001). Efficacy of Powders of some tropical plants in the control of the pulse beetle, callosobruchus maculatus (F.) (Coleoptera: Bruchidae) Journal of Applied Tropical Agriculture 11-15

Akaeze, H.O., 2010. Consumer preference for imported rice in Nigeria-perceived quality differences or habit persistence? Thesis Submitted to Michigan State University for the Degree of Master of Science Agricultural, Food and Resource Economics, UMI Dissertation Publishing.

Aremu, M. B., Sanni, A. A. \& Maji, A. T. (2013). Microbiological Quality Assessment of Rice Sold by Food Vendors around some Health Centres in Ilorin Metropolis. International Journal of Applied Research and Technology, 2(11), 26 - 35

Canno P. F. \& Kirk P. M. (2007). Fungal Family of the world. Wallingford UK, CABI:Singapore. 456

Emery, R. N. \& Nayak, M. K. (2007). Pests of stored grains. In: Pests of field crops and pastures. Australia: Identification and Control [ed. by Bailey, P. T.]., Australia: Identification and Control CSIRO Publishing, 40-61.

Ezeji, J. (2009). "The Travails of Nigerian Rice.” http://joachimibeziakoezeji.blogspot.com/2009/06/travails -of-nigerian-rice.html.

Imohelin, E. D. 1983. "Rice Seed Borne Fungi and Their Effect on Seed Germination." Plant Diseases 67 (12), 1-3. 
Iwuagwu, C. C., Umechuruba, C. I., Ononuju, C. C. \& Nwogbqa, A. C.(2018). Assessment of Seed-Borne Plant Pathogenic Fungi associated with Rice Crop in South-Eastern Nigeria. Journal of Agricultural, Science and Technology A(8), 68-75

Mew, T.W. \& Gonzales, P. (2002). A Handbook of Rice Seed borne Fungi. International Rice Research Institute, Los Banós, Philippines. 83

Omofonmwan, S. I. \& Kadiri, M. A. (2007). "Problems and Prospect of Rice Production in Central District of Edo State." Nigeria Journal of Humid Ecology 22 (2), 123-8.

Oludare, A. O. (2014) 'Analysis of the efficiency of mechanized and non-mechanized rice production in Kaduna State, Nigeria'

Ora, N., Farua, A. N., Islam, M. T., Akhtar N., \& Rahman, M. M. (2011). "Detection and Identification of Seed Borne Pathogens from Cultivated Hybrid Rice Varieties in Bangladesh." Middle-East Journal of Scientific Research 10 (4), 482-8.

Perez-Mendoza, J., Flinn, P.W., Campbell, J. F., Hagstrum, D. W., Throne, J. E.(2004). Detection of Stored-Grain Insect Infestation in Wheat Transported in Railroad HopperCars. Journal of Economic Entomology, 1474- 1482

Pritchard, H.W. \& Dickie, J.B. (2004) Predicting seed longevity: the use and abuse of seed viability equations. pp. 653-722 in Smith, R.D.; Dickie, J.B.; Linington, S.H.; Pritchard, H.W.; Probert, R.J. (Eds) Seed conservation: turning science into practice. Kew, London, Royal Botanic Gardens Kew

Suleiman, M. N., and Akaajime, D. (2010). "Isolation and Physiological Studies of Fungus Associated with Rice Grain (Oryza stativa) in Makurdi, Benue State.” Nigeria Advances in Governmental Biology 4 (2): 168-71.

Togola, A., Seck, P.A., Glitho, I.A., Diagne, A., Adda, C., Toure A. \& Nwilene, F.E. (2013). Economic Losses from Insect Pest Infestation on Rice Stored on-farm in Benin. Journal of Applied Sciences, 13: 278-285.

Udemezue, J.C. (2018). Analysis of Rice Production and Consumption Trends in Nigeria. Journal Plant Science and Crop Protection 1(3), 305

Udemezue JC (2014) Adoption of FARO- 44 Rice production and Processing Technology by farmers in Anambra State. Post Graduat thesis, Department of Agricultural Extension University of Nigeria, Nsukka 1-55

USDA/ Grain and Feed Annual Report 2019

Vidotto, F \& Ferrero, A (2000). Germination behaviour of red rice (Oryza stiva L.) seeds in field and laboratory conditions. Agronomie. 20, 375-382

Utobo, E. B., Ogbodo, E. B., and Nwogbaga, A. C. (2011). "Seed Borne Mycoflora Associated with Rice and Their Influence on Growth at Abakiliki, Southeast AgroEcology, Nigeria. Libyan Agriculture Research Centre.” Journal International 2 (2): 79-84. 